\title{
Penguatan Pengaturan Hak Anak Berdasarkan Konstitusi dan Perbandingan Konstitusi Diberbagai Negara
}

\author{
Ismail Aris \\ Dosen Tetap Sekolah Tinggi Agama Islam (STAI) Al Gazali Bone \\ Ismail.aris239@gmail.com
}

\begin{abstract}
This article shows that the constitution or the 1945 Constitution of the Republic of Indonesia can not be regarded as children's constitution which adopts the principles of child protection under the Convention on the Rights of the Child. It also shows that Indonesia is not serious about the theme of child protection discourse such as Ecuador, Egypt, Finland and South Africa in protecting, fulfilling and respecting and explicitly specifying the rights of children in its constitution. Based on the argument above, it is very urgent for Indonesia to do constitutionalism the rights of the child. Based on the principles that adopted by the convention on the right of the child as a solution as an effort to save and protect the rights of the child from negligence and neglect of the State to protect and fulfill the human rights and constitutional rights of the child. The effort of constitutionalism is also considered as a strengthening effort in the formation of legislation in the future as well as the basis or test stone of the Constitutional Court in handling the future judicial review of the Law which violates the norm on the protection of children's rights under the Constitution. In addition, it is urgent for constitutionalism and incorporates the idea of constitutional complaints in the Constitutional Court through the Constitution. Thus, as a basis for constitutional protection of the child if the State has neglect to protect the human rights and constitutional rights of the child by conducting constitutional complaint in the Constitutional Court, in order for the State to fulfill its constitutional obligations which have been regulated under the constitution.
\end{abstract}

Keywords: Protection of the Rights of the Child, Constitution, Comparative Constitution in Various Countries

\section{Pendahuluan}

Anak sebagai generasi penerus bangsa yangi secara alami masih sangat rawan untuk berbagai hambatan dan tantangan dalam kehidupannya tentunya mendapat tempat yang paling penting untuk mendapat perlindungan pemerintah Dalam pasal 28B UUD NRI Tahun 1945 disebutkan bahwa negara menjamin setiap anak untuk hidup, tumbuh dan berkembang serta berhak atas perlindungan dari kekerasan dan diskriminasi. Pasal ini mempunyai korelasi dengan pasal 28G yang menyatakan bahwa setiap orang berhak atas perlindungan diri pribadi, keluarga, kehormatan, martabat, dan harta benda yang di bawah kekuasaan, serta berhak atas rasa aman dan perlindungan dari ancaman ketakutan untuk berbuat sesuatu yang merupakan hak asasi. Pasal 52 dan 66 Undang-Undang Nomor 39 Tahun 1999 tentang Hak Asasi Manusia juga 


\section{An-Nisa', Volume XI Nomor 1 Januari 2018}

menyebutkan mengenai hak-hak sipil, politik, dan cultural anak yang perlu dihargai dan dilindungi.

Selanjutnya dalam pasal 59 Undang-Undang Nomor 23 Tahun 2002 tentang Perlindungan Anak dikatakan, bahwa pemerintah dan lembaga negara lainnya berkewajiban dan bertanggung jawab untuk memberikan perlindungan khusus kepada anak dalam situasi darurat, anak yang berhadapan dengan hukum, anak dari kelompok minoritas dan terisolasi, anak terereksploitasi secara ekonomi dan/ atau seksual, anak yang diperdagangkan, anak yang menjadi korban penyalahgunaan narkotika, alcohol, psikotropika, dan zat adiktif lainnya (napza), anak korban penculikan, penjualan dan perdagangan, anak korban kekerasan baik fisik dan/ atau mental, anak yang mengandung cacat, dan anak korban perlakuan salah dan penelantaran.

Fakta lainnya, menunjukkan berbagai kasus kekerasan telah terjadi, diantaranya : Almarhum Dede mati karena dibunuh oleh alah tirinya; Anggi (6 tahun) telah memperoleh kekerasan dari ibunya ; Lintang dan almarhum Indah yang menjadi korban ibunya; Ismi yang telah menjadi korban dari ibu suri tempat ia tinggal; Riska Rosdiana (7 th) yang dicekik oleh ibu tirinya dan kemudian diperkosa oleh adik ibu tirinya; Tia yang telah menjadi korban setrika dari ayahnya karena dituduh mencuri; dan kasus paling baru adalah Nia Siahaan (2 th) di Manado yang mendapat luka pisik dari ayah tirinya. Mereka adalah anak-anak korban kekerasan yang bukan saja menderita secara fisik tapi juga psikis. Rasa ketakutan yang terus membayangi adalah dampak dari kekerasan yang mereka terima.

Dengan adanya gap dan issu hukum a quo, hal itu merupakan sebagai landasan konstruksi berpikir dalam merumuskan issu hukum yang harus dijawab, sehingga penelitian ini menjadi terarah dan sistematis.

\section{Subtansi Pengaturan Hak Anak Perspektif Konstitusi dan berbagai permasalahannya}

\section{Konsepsi tentang Perlindungan Anak perspektif Tata Hukum Nasional}

Secara konstitusional hak asasi dan hak konstitusional anak sudah dijamin, dilindungi, dan diatur dalam UUD NRI Tahun 1945 yakni berdasarkan Pasal 28B ayat (2) yang mengatur bahwa: Hak atas kelangsungan hidup, tumbuh, dan berkembang serta berhak atas perlindungan 
dari kekerasan dan diskriminasi. Sedangkan, terkait hak jaminan kesejahteraan anak diatur berdasarkan Pasal 34 ayat (1) yang mengatur bahwa: Anak-anak yang terlantar dipelihara oleh Negara. Adapun peraturan perundang-undangan yang dimaksud telah mengatur konsepsi tentang anak, yakni sebagai berikut :

- Konvensi Hak Anak diratifikasi pada 1990 (dengan Keputusan Presiden No 36) mendefinisikan usia di bawah 18 untuk mendefinisikan anak-anak kecuali, di bawah hukum, kedewasaan tercapai sebelumnya;

- Konvensi ILO No 138 dan diratifikasi oleh Undang-undang Nomor 20 Tahun 1999 menyatakan dasar usia minimum untuk bekerja di Indonesia adalah 15;

- Undang-undang No 35 Tahun 2014 tentang Perlindungan Anak mendefinisikan bahwa anak sebagai orang-orang yang berusia di bawah 18 tahun, termasuk bayi yang masih dalam rahim ibu mereka;

- Undang-Undang No. 13 Tahun 2003 tentang Ketenagakerjaan mendefinisikan tenaga kerja anak-anak adalah mereka yang kurang dari 18 tahun.

Berkaitan dengan perlindungan anak-anak dari efek buruk bekerja, Keppres No.59 Tahun 2002 telah dikeluarkan dan diidentifikasi 13 jenis bentuk-bentuk terburuk pekerja anak yaitu:

1. Mempekerjakan anak-anak sebagai pelacur.

2. Mempekerjakan anak-anak di pertambangan.

3. Mempekerjakan anak-anak sebagai penyelam mutiara.

4. Mempekerjakan anak-anak di bidang konstruksi.

5. Menugaskan anak-anak di anjungan penangkapan ikan lepas pantai (yang di Indonesia disebut jermal).

6. Mempekerjakan anak-anak sebagai pemulung.

7. Melibatkan anak-anak dalam pembuatan dan kegiatan yang menggunakan bahan peledak.

8. Mempekerjakan anak-anak di jalanan.

9. Mempekerjakan anak-anak sebagai tulang punggung keluarga.

10. Mempekerjakan anak-anak di industri rumah tangga (cottage industries). 


\section{An-Nisa', Volume XI Nomor 1 Januari 2018}

11. Mempekerjakan anak-anak di perkebunan.

12. Mempekerjakan anak-anak dalam kegiatankegiatan yang berkaitan dengan usaha penebangan kayu untuk industri atau mengolah kayu untuk bahan bangunan dan pengangkutan kayu gelondongan dan kayu olahan.

13. Mempekerjakan anak-anak dalam berbagai industri dan kegiatan yang menggunakan bahan kimia berbahaya.

Dalam perkembangannya ${ }^{96}$, konsepsi tentang anak termasuk anak yang masih berada dalam kandungan sebagaimana diatur berdasarkan Undang-Undang Republik Indonesia Nomor 21 Tahun 2007 tentang Anti Trafficking. Berdasarkan pada Pasal 1, mengatur bahwa : mengharuskan seorang anak adalah seseorang yang belum berusia 18 (delapan belas) tahun, termasuk anak-anak yang masih dalam kandungan.

\section{Problematika Pemenuhan dan Perlindungan Hak Kependudukan Anak}

Deklarasi Universal Hak Asasi Manusia Perserikatan Bangsa-Bangsa tenta Konvensi Hak Anak berdasarkan pada Pasal 7 section I yang mengatur bahwa : “Anak harus didaftarkan segera setelah kelahirannya, dan sejak kelahirannya berhak untuk memperoleh sebuah nama, untuk memperoleh kewarganegaraan, dan, sebisa mungkin, untuk mengetahui orang tuanya dan dibesarkan oleh orang tuanya".

Dalam tata hukum nasional, secara konstitusional bahwa hak anak merupakan obligatori Negara untuk pengakuan, jaminan, perlindungan, dan kepastian hukum yang adil serta perlakuan yang sama dihadapan hukum. ${ }^{97}$ A forteriori, jaminan konstitusional terhadap setiap orang berhak atas status kewarganegaraan. Selain itu, juga ditegaskan obligatori Negara a quo, berdasarkan Pasal 28 Undang-Undang No. 35 Tahun 2014 Tentang Perlindungan Anak, bahwa merupakan obligatori dari Negara untuk pemenuhan hak anak terhadap hak dibidang kependudukan yang dijamin oleh hukum in casu, Pembuatan akta kelahiran dilakukan oleh instansi yang menyelenggarakan urusan pemerintahan di bidang administrasi kependudukan.

\footnotetext{
${ }^{96}$ Masih banyak norma hokum di bawah tingkatan undang-undang yang tidak sempat penulis kutip dengan alasan hanya mengatur lebih lanjut undang-undang yang telah dikutip serta kajian ini lebih focus terhadap kajian konstitusi.

${ }^{97}$ Pasal 28D Ayat (1) UUD NRI Tahun 1945
} 
Dalam realitasnya, menurut Ketua Komisi Nasional Perlindungan Anak (Komnas PA), Arist Merdeka Sirait, mengatakan berdasarkan data Badan Pusat Statistik (BPS) tahun 2012, terdapat 50 juta anak Indonesia yang belum memiliki akta kelahiran. Menurut Kemendagri, bahwa data kepemilikan akta kelahiran anak sepanjang 2014-2016. Pada 2014, sebanyak 21.552.814 anak atau sebesar 31,25 persen dari jumlah anak 68.969.005. Pada 2015, 51.484.076 anak atau sebesar 61,62 persen dari jumlah 83.551.734. Pada 2016, 57.043.076 anak atau sebesar 74,29 persen dari jumlah anak 77.309.969 anak. $^{98}$

Uraian fakta tersebut, menunjukkan pemerintah melakukan pengabaian terhadap tanggung jawab konstitusionalnya terhadap pemenuhan Hak Asasi Anak dibidang kependudukan.

\section{Problematika Pemenuhan dan Perlindungan Hak Anak atas Pendidikan}

Jaminan Konstitusional terkait dengan hak dibidang pendidikan yang dijamin berdasarkan Konstitusi NRI Tahun 1945 bahwa Negara harus to respect, to fulfill dan to protect warga negara wajib mengikuti pendidikan dasar dan pemerintah wajib membiayainya. Disisi lainnya, juga terdapat hukum perkawinan berdasarkan Undang-Undang No. 1 Tahun 1974 yang memberikan hak kepada anak menikah di usia 16 Tahun dan 18 Tahun bagi laki-laki. Tahun 2015 persentase perempuan usia 20-24 berstatus cerai hidup dan menikah sebelum usia 18 tahun sebesar 4,53 persen, sementara persentase yang menikah setelah usia 18 tahun lebih rendah yaitu 3,02 persen. Di perkotaan, perbedaan tingkat perceraian antara kelompok yang menikah sebelum usia 18 tahun dan 18 tahun ke atas lebih besar dibandingkan di perdesaan. ${ }^{99}$ Tahun 2015 , di perkotaan persentase perempuan usia 20-24 tahun yang menikah sebelum usia 18 tahun yang sudah bercerai sebesar 7,02 persen, sedangkan perempuan yang menikah pada usia 18 tahun ke atas yang berstatus cerai hidup hanya 3,06 persen. Tingkat perceraian pada perempuan usia 2024 tahun yang menikah sebelum usia 18 tahun cenderung meningkat pada periode tahun 2013 dan tahun 2015. Persentase perceraian pada perempuan pelaku pernikahan usia anak di tahun 2013 yaitu 4,31 persen, tahun 2015 meningkat menjadi 4,53 persen. Tingkat perceraian

\footnotetext{
98 http://sp.beritasatu.com/home/hampir-20-juta-anak-indonesia-belum-miliki-akte-kelahiran/118592. Diakses pada tanggal 10 Juni 2018

${ }^{99}$ BPS RI. 2016. Perkawinan Usian Anak di Indonesia (2013-2015), h. 10.
} 
perempuan yang menikah usia anak di perkotaan lebih tinggi dibandingkan perdesaan. Pada tahun 2015 persentase perempuan usia 20-24 tahun yang menikah sebelum usia 18 tahun yang sudah bercerai di perkotaan 7,02 persen, sedangkan di perdesaan persentasenya 3,36 persen. ${ }^{100}$ Bahkan Lebih detail terhadap angka tersebut sebagaimana pada table dibawah ini :

Tabel Angka Status Perkawinan Anak

\begin{tabular}{|c|c|c|c|c|c|c|c|}
\hline \multirow{3}{*}{ Tutiuge } & \multirow{2}{*}{ Perlewewingur } & \multicolumn{6}{|c|}{ 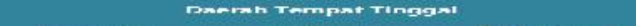 } \\
\hline & & -18 & $18+$ & -18 & $18+$ & & \\
\hline & & $\frac{(0)}{(0)}$ & (1) & $(5)$ & $(c)$ & $\frac{172}{35}$ & 503 \\
\hline \multirow{4}{*}{ xom } & Kuming & $0.2,55$ & 60,74 & 50.0 .4 & 07.56 & 05,2 & 07,18 \\
\hline & ar.enthesur & $\therefore \Delta$ & 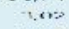 & sene? & $\therefore 1$ & 1.11 & $\because \cdots 1$ \\
\hline & Etwi Muti & 0.18 & 0.21 & 0.30 & 0.31 & 0.10 & 0.28 \\
\hline & k⿻ums & $m$, & wis... & co. $\cdots$ & a.t... & 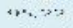 & ar...<icz \\
\hline \multirow[t]{2}{*}{ x+1. } & Gerthi U tictup? & ,... & $-3,0100$ & s...ses & $\therefore \cdots$ & $\therefore$ & 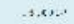 \\
\hline & anm matr & $\therefore, \infty=$ & $\therefore \cdots$ & $x: 2$, & $6 . \times n$ & 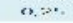 & $\Leftrightarrow \geqslant \infty$ \\
\hline
\end{tabular}

\section{Sumber : BPS RI. 2016. Perkawinan Usian Anak di Indonesia (2013-2015).}

Data di atas menunjukkan tingginya angka anak yang kawin sebelum berumur 18 Tahun dan dapat asumsikan bahwa factor perkawinan anak dibawah umur yang seharusnya direduksi berimplikasi terhadap angka partisipasi sekolah anak diakibatkan oleh perkawinan.

Tabel Status Perkawinan anak dan Partisipasi sekolah Tahun 2015

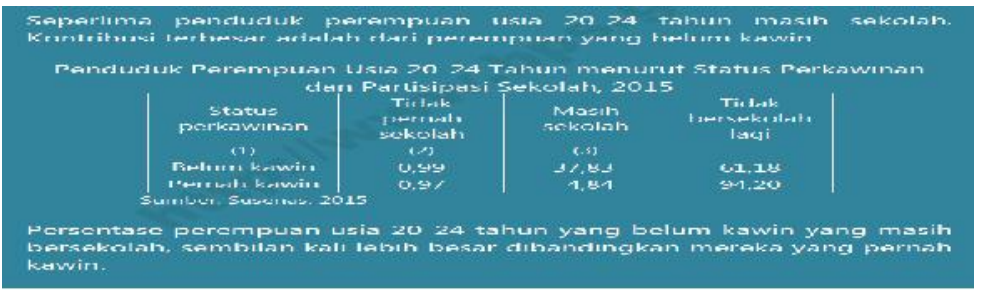

\section{Sumber : BPS RI.}

Data diatas menunjukkan bahwa Sekolah dan perkawinan usia anak mempunyai keterkaitan yang bersifat kausalitas.

\section{Status Emergency Pemenuhan dan Perlindungan Hak Anak di Indonesia}

Problematika terhadap pemenuhan dan perlindungan hak anak atas kelangsungan hidup, tumbuh, dan berkembang serta berhak atas perlindungan dari kekerasan dan diskriminasi yang telah dijamin secara konstitusional. Realitas a quo, sebagaimana pada table dibawah ini berdasarkan data Komisi Perlindungan Anak Indonesia (KPAI), sebagi berikut :

Tabel. Rincian Data Kasus Trafficking dan Eksploitasi Tahun 2015

\begin{tabular}{|c|c|c|}
\hline NO & KASUS PERLINDUNGAN ANAK & TOTAL \\
\hline $\mathbf{1}$ & Anak Sebagai Korban Perdagangan (Trafficking) & 48 \\
\hline
\end{tabular}

\footnotetext{
${ }^{100}$ BPS RI. 2016. Perkawinan Usian Anak di Indonesia (2013-2015), h. 11.
} 
An-Nisa', Volume XI Nomor 1 Januari 2018

\begin{tabular}{|c|c|c|}
\hline $\mathbf{2}$ & Anak Sebagai Korban Prostitusi Online & 96 \\
\hline $\mathbf{3}$ & Anak Sebagai Korban Eksploitasi Seks Komersial Anak (ESKA) & 61 \\
\hline $\mathbf{4}$ & Anak Sebagai Korban Eksploitasi Pekerja Anak & 84 \\
\hline \multicolumn{2}{|c|}{ Total } & $\mathbf{2 8 9}$ \\
\hline
\end{tabular}

\section{Sumber : Komisi Perlindungan Anak Indonesia (KPAI)}

Berdasarkan dari data tersebut diatas, menunjukkan bahwa anak di Indonesia merupakan peringatan status darurat pemenuhan dan perlindungan hak anak. Selain itu, juga menunjukkan bahwa Negara belum memandang issu perlindungan anak merupakan issu internasional dan nasional Hal tersebut, dibuktikan dengan Kasus Berdasarkan Klaster Perlindungan Anak, 20112016. Lebih detail sebagai berikut :

Rincian Data Kasus Berdasarkan Klaster Perlindungan Anak, 2011-2016

\begin{tabular}{|c|c|c|c|c|c|c|c|}
\hline Kasus perlindungan anak & 2011 & 2012 & 2013 & 2014 & 2015 & 2016 & Jumlah \\
\hline $\begin{array}{l}\text { Sosial dan Anak Dalam Situasi } \\
\text { Darurat }\end{array}$ & 92 & 79 & 246 & 191 & 174 & 148 & 930 \\
\hline $\begin{array}{l}\text { Anak Terlantar (Anak Penyandang } \\
\text { Masalah Kesejahteraan Sosial) }\end{array}$ & 54 & 39 & 69 & 84 & 74 & 63 & 383 \\
\hline $\begin{array}{l}\text { Anak Dalam Keadaan Darurat } \\
\text { (Korban Konflik Sosial / Peperangan) }\end{array}$ & 17 & 22 & 44 & 19 & 14 & 11 & 127 \\
\hline $\begin{array}{l}\text { Anak Korban Bencana (Darat, Laut, } \\
\text { Udara) }\end{array}$ & 21 & 18 & 133 & 88 & 86 & 74 & 420 \\
\hline Keluarga dan Pengasuhan Alternatif & 416 & 633 & 931 & 921 & 822 & 571 & 4.294 \\
\hline $\begin{array}{l}\text { Anak Korban Perebutan Hak Kuasa } \\
\text { Asuh }\end{array}$ & 166 & 278 & 368 & 374 & 287 & 186 & 1.659 \\
\hline $\begin{array}{l}\text { Anak Korban Pelarangan Akses } \\
\text { Bertemu Orangtua }\end{array}$ & 132 & 166 & 256 & 282 & 312 & 193 & 1.341 \\
\hline $\begin{array}{l}\text { Anak Korban Penelantaran Ekonomi } \\
\text { (Hak Nafkah) }\end{array}$ & 94 & 154 & 237 & 223 & 182 & 124 & 1014 \\
\hline Anak Hilang & 24 & 35 & 70 & 42 & 41 & 21 & 233 \\
\hline Agama dan Budaya & 83 & 204 & 214 & 106 & 180 & 171 & 958 \\
\hline \multirow{2}{*}{ Total } & 2011 & 2012 & 2013 & 2014 & 2015 & 2016 & \multirow{2}{*}{11.359} \\
\hline & 1099 & 1.628 & 2.568 & 2.330 & 2.172 & 1.562 & \\
\hline
\end{tabular}

Sumber : Data diolah berdasarkan data mentah dari Komisi Perlindungan Anak Indonesia (KPAI) RI. ${ }^{101}$

Selain data perlindungan anak sebagaimana diatas, kasus tidak terpuhinya hak anak dibidang kesehatan, 1.872 anak yang terkena HIV AIDS berdasarkan data Kementrian

${ }^{101}$ Lihat,bankdata.kpai.go.id/tabulasi-data/data-kasus-per-tahun/rincian-data-kasus-berdasarkan-klasterperlindungan-anak-2011-2016. Diakses pada tanggal 10 Juni 2018. 
kesehatan ${ }^{102}$ pada tahun 2016. Sedangkan, Jumlah penyalahgunaan narkoba terbesar berdasarkan data terakhir pada tahun 2017 menurut Badan Narkotika Nasional (BNN) RI ${ }^{103}$ adalah termasuk dikalangan anak atau pelajar. Adapun data terkait dengan penyalaguna narkoba yang melibatkan anak pelajar a quo, sebagai berikut :

Tabel diagram Data Hasil survey Penyalahguna Narkoba tahun 2017

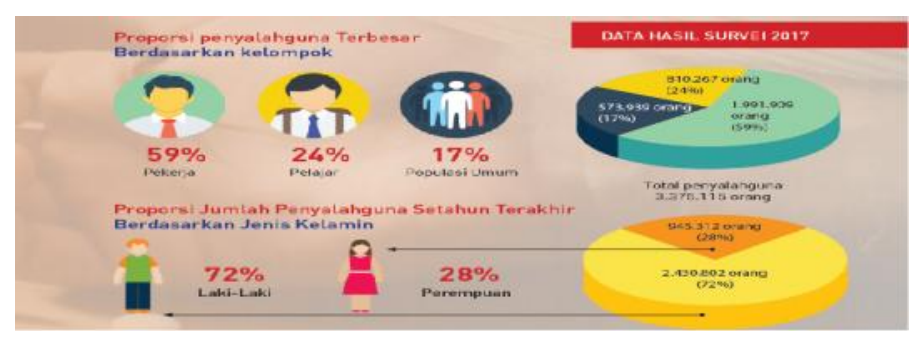

Sumber : Badan Narkotika Nasional (BNN) RI, Survei Nasional Penyalahguna Narkoba di 34 Provinsi Tahun 2017.

\section{Perbandingan Pengaturan Hak Anak Perspektif Konstitusi diberbagai Negara}

1. Pengalaman di berbagai Negara terkait dengan Hak Anak berdasarkan Konsitusi

a. Ekuador

Di Ekuador, berdasarkan pada Article 46 pada section 1, yang pada pokoknya anak harus dilindungi terkait dengan nutrisinya atau perlindungan dari gizi buruk, kesehatan, pendidikan. detailnya sebagai berikut: The State shall adopt, among others, the following measures that safeguard children and adolescents: 1. Care for children under six years of age that guarantees their nutrition, health, education and dairy care in a framework of integral protection of their rights. ${ }^{104}$

b. Finlandia

Di Negara Finlandia, pemenuhan hak dibidang pendidikan terhadap anak memiliki jamna konstitusionalitas berdasarkan pada Article (section) $16^{105}$ yang pada pokoknya mengatur

\footnotetext{
${ }^{102}$ Lihat lebih detail pada data Kemenkes, Situasi Penyakit HIV AIDS di Indonesia, Pusat Data dan Informasi Kementrian Kesehatan Republik Indonesia, Jakarta Selatan, 2016.

${ }^{103}$ Badan Narkotika Nasional (BNN) RI, Survei Nasional Penyalahguna Narkoba di 34 Provinsi Tahun 2017, Pusat Penelitian dan Informasi, 2017, h. 29.

${ }^{104}$ Ecuador's Constitution of 2008 with Amendments through 2015. constituteproject.org. PDF generated: 28 Mar 2017, 17:23

${ }^{105}$ Finland's Constitution of 1999 with Amendments through 2011. constituteproject.org. PDF generated: 28 Mar 2017, 17:24.
} 
sebagai berikut : Educational rights Everyone has the right to basic education free of charge. Provisions on the duty to receive education are laid down by an Act.

c. Mesir

Di Negara Mesir, Negara berkomitmen untuk melindungi perempuan dari segala bentuk kekerasan, dan memastikan pemberdayaan perempuan untuk mendamaikan tugas perempuan terhadap keluarganya dan persyaratan pekerjaannya. Negara menjamin perawatan dan perlindungan dan merawat ibu dan anak, dan untuk pencari nafkah, dan wanita lanjut usia, dan wanita yang paling membutuhkan.

d. Afrika Selatan

Di afrika selatan, yang dapat dikategorikan sebagai anak in casu, anak yang berumur dibawah 18 Tahun. Hal tersebut, sebagaimana dalam konstitusi Afrika Selatan pada article 28 Ayat (3) ${ }^{106}$, sebagai berikut : (3) In this section "child" means a person under the age of 18 years. Tema perlindungan anak di negara Afrika Selatan, diatur berdasarkan konstitusi Negara afrika selatan sebagaimana pada Article 28 Ayat (1), yang pada pokoknya sebagai berikut : Children; (1) Every child has the right- (a) to a name and a nationality from birth ${ }^{107}$; (b) to family care or parental care, or to appropriate alternative care when removed from the family environment; (c) to basic nutrition ${ }^{108}$, shelter, basic health care services and social services ${ }^{109}$; (d) to be protected from maltreatment, neglect, abuse or degradation; (e) to be protected from exploitative labour practices ${ }^{110} ;(f)$ not to be required or permitted to perform work or provide services that- (i) are inappropriate for a person of that child's age; or (ii) place at risk the child's well-being, education, physical or mental health or spiritual, moral or social development ${ }^{111}$.

\section{Penguatan Pengaturan yang Ideal mengenai Perlindungan Anak Melalui Upaya Konstitusionalisasi}

Uapaya Penguatan Pengaturan yang Ideal mengenai Perlindungan Anak Melalui Upaya Konstitusionalisasi, menurut, Nadine Perrault, reformasi hukum dalam konteks pembentukan norma konstitusi hak anak dapat diinisasi melalui 2 (dua) proses yakni: ${ }^{112}$

\footnotetext{
${ }^{106}$ South Africa's Constitution of 1996 with Amendments through 2012. constituteproject.org. PDF generated: 28 Mar 2017, 17:36.

${ }^{107} \mathrm{Hak}$ anak dibidang kependudukan in casu akte kelahiran.

${ }^{108}$ Ketentuan tersebut mengatur Hak nutrisi anak untuk melindungi anak dari gizi buruk.

${ }^{109}$ Jaminan Sosial dan layanan kesehantan terhadap anak.

${ }^{110}$ Ekspolitasi anak sebagai tenaga kerja

${ }^{111}$ Hak anak dibidang pendidikan, pembangunan karakter anak di Afrika Selatan.

${ }^{112}$ Adzkar Ahsinin, Menjamin Perlindungan Anak melalui Konstitusi: Urgensi Amandemen UUD 1945 Menuju Konstitusi Anak (Child Constitusion), h. 6
} 


\section{An-Nisa', Volume XI Nomor 1 Januari 2018}

a. Memformulasikan konstitusi yang baru

b. Merivisi atau mengamandemen konstitusi yang telah ada.

Gagasan oleh Nadine Perrault a quo, memiliki relevansi dengan pendapat Mosikatsana T.L yang mengharuskan pengaturan prinsip-prinsip dan norma-norma konvensi hak anak menjadi norma konstitusi sangat signifikan dalam mengimplementasikan KHA secara efektif di Negara pihak karena konstitusionalitas tersebut akan berdampak positif sebagai berikut : ${ }^{113}$

a. Pengaturan prinsip-prinsip dan norma-norma KHA dalam konstitusi secara spesifik akan memicu dan memberikan loncatan bagi upaya reformasi legislatif;

b. Kemanfataan minimal, konstitusionalitas akan memberikan legitimasi bagi wacana politik hak-hak anak dan memberikan justifikasi politik bagi pemerintah dalam menetapkan dan mengeluarkan anggaran untuk program sosial bagi anak-anak;

c. Dengan adanya alokasi pengaturan khusus bagi hak anak pada hukum tertinggi (supreme law) negara, maka anak secara legal dilekati hak dan dipandang sebagai subyek hak;

d. Anak dimungkinkan untuk melakukan tuntutan (claim) substansial kepada negara karena anak memiliki hak konstitusional yang harus dijamin dan dilindungi;

e. Memungkin anak mempergunakan mekanisme hukum sebagai upaya untuk melindungi dari erosi kemanfaatan sosial yang seharusnya menjadi kewajiban negara;

f. Meningkatkan justisiablitas hak anak sehingga hak anak dapat ditegakkan;

g. Penawaran pemerintah dapat terjustifikasi secara politik untuk penyediaan dan kemanfaatan bagi anak sehingga isu anak menjadi prioritas dalam pendistribusian sumber daya yang terbatas;

h. Memberikan justifikasi secara moral dan legal terhadap pemerintah untuk menetapkan pengeluaran belanja untuk kesejahteraan sosial karena akan mempengaruhi kebijakan fiskal di suatu Negara.

\section{Penutup}

Urgensi penguatan perlindungan anak di Indonesia, tidak terlepas dari realitas emergency dan issu global terhadap status pemenuhan dan perlindungan anak. Meskipun secara konstitusional diatur hak anak. Tetapi, Konstitusi atau UUD NRI Tahun 1945 belum dapat dikatakan sebagai children's constitution. Sehingga, Negara Indonesia tidak mendudukkan anak

113 Adzkar Ahsinin, Menjamin Perlindungan Anak melalui Konstitusi: Urgensi Amandemen UUD 1945 Menuju Konstitusi Anak (Child Constitusion), Sebuah Penjajakan Awal, h. 6-7 
sebagai asset besar dan jumlah anak di Indonesia sebagai plus demografi untuk generasi penerus pada pembangunan peradaban bangsa in the future. Hal tersebut menunjukkan, Indonesia tidak serius dengan tema diskursus perlindungan anak seperti Negara Ecuador, Mesir, Finlandia, dan Afrika Selatan dalam melindungi, memenuhi, dan menghormati hak-hak anak.

Dengan argumentasi demikian, sangat urge Negara Indonesia untuk melakukan konstitusionalisasi hak anak sesuai dengan prinsip yang dianut konvensi tentahg hak anak sebagai solusi dianggap penting sebagai upaya penyelamatan dan perlindungan anak dari korban kejahatan. Upaya penguatan tersebut juga sebagai umbrella act dalam pembentukan peraturan perundang-undangan kedepannya serta sebgai dasar atau batu uji Mahkamah Konstitusi dalam menangani Judicial review kedepannya terhadap Undang-Undang yang melabrak Konstitusi.

\section{Daftar Rujukan}

Affandi, Hernadi. Hak Asasi Manusia, Pemerintahan yang Baik, dan Demokrasi di Indonesia (Bandung: CV Kancana Salakadomas, 2013.

Ahsinin, Adzkar. Menjamin Perlindungan Anak melalui Konstitusi: Urgensi Amandemen UUD 1945 Menuju Konstitusi Anak (Child Constitusion), Sebuah Penjajakan Awal, Yayasan Pemantau Hak Anak (Children Human Right's Foundation). tanpa tahun,

Asshidiqie, Jimly. Konstitusi dan Konstitusionalisme, Jakarta : Konstitusi Press, 2005.

Badan Narkotika Nasional (BNN) RI, Survei Nasional Penyalahguna Narkoba di 34 Provinsi Tahun 2017, Pusat Penelitian dan Informasi Badan Narkotika Nasional (BNN) RI, 2017.

BPS RI. 2016. Perkawinan Usian Anak di Indonesia (2013-2015).

Ecuador's Constitution of 2008 with Amendments through 2015. constituteproject.org. PDF generated: 28 Mar 2017, 17:23

Egypt's Constitution of 2014. constituteproject.org PDF generated: 11 Mar 2015, 16:26

Finland's Constitution of 1999 with Amendments through 2011. constituteproject.org. PDF generated: 28 Mar 2017, 17:24.

http://www.hukumonline.com/berita/baca/lt5792447bd5551/terabaikan--50-juta-anak-indonesiatidak-memiliki-akta-kelahiran. 


\section{An-Nisa', Volume XI Nomor 1 Januari 2018}

Kemenkes, Situasi Penyakit HIV AIDS di Indonesia, Pusat Data dan Informasi Kementrian Kesehatan Republik Indonesia, Jakarta Selatan, 2016.

Mulyadi, Mohammad. Pelanggaran Hak Anak, Jurnal Negara Hukum, Vol. V, No. 06/II/P3DI/Maret/2013, h. 11

South Africa's Constitution of 1996 with Amendments through 2012. constituteproject.org. PDF generated: 28 Mar 2017, 17:36

Stone Sweet, Alec, What is a Supranational Constitution?: An Essay in International Relations Theory Yale Law School Legal Scholarship Repository, 1994.

Syahrizal, Ahmad. Peradilan Konstitusi Suatu Studi tentang Adjudikasi Konstitusional Sebagai Mekanisme Penyelesaian Sengketa Normatif, Jakarta: PT. Pradnya Paramita. 2006.

Undang-Undang No. 11 Tahun 2012 Tentang Sistem Peradilan Anak

Undang-Undang Nomor 23 Tahun 2003 tentang Sistem Pendidikan Nasional

Wignyosoebroto, Soetandyo. Hak-Hak Asasi Manusia dan Konstitutionalisme: Hubungan Antara Masyarakat dan Negara, dalam Hukum, Paradigma, Metode dan Dinamika Masalahnya, Jakarta: Elsam-HuMa, 2002. 